\title{
Penggunaan KJR (Kartu dan Jurnal Refleksi) untuk Optimalisasi Pembelajaran Tematik Kurikulum 2013 di Kelas V SD Pesurungan Lor 2 Kota Tegal
}

\author{
Astrinuari Primanda \\ SD Negeri Pesurungan Lor 2 Kota Tegal \\ astrinr.prmnd141@gmail.com
}

Article History

received 3/12/2020

revised 17/12/2020

accepted $31 / 12 / 2020$

\begin{abstract}
This research was carried out based on problems that occurred in thematic learning in 5th Grade SD Pesurungan Lor 2 Tegal City. Teachers have difficulty in teaching and evaluating learning outcomes. Students have difficulties to learn materials so that they hinder the learning process and are unable to master the competencies required in the Curriculum 2013. The purpose of the reasearch to: (1) innovate in optimizing the understanding of thematic learning materials in the Curriculum 2013; (2) to find out the understanding of 5th Grade students about the thematic learning materials for the Curriculum 2013; (3) to improve the thematic learning outcomes of 5th Grade students. This research uses Fishbone Analysis and GAP Analysis methods. The use of Reflection Cards is carried out by students every time they finish the thematic learning by writing down what has been learned and conveying the contents of the Reflection Card so that students can remember the previous material. The Reflection Journal is filled in by the teacher by paying attention to the results of the Reflection Card. The use of Reflection Cards and Journals has an effect on increasing students' understanding and learning outcomes.
\end{abstract}

Keywords: reflection cards, reflection journals, thematic learning

\begin{abstract}
Abstrak
Penelitian ini dilaksanakan berdasarkan permasalahan yang terjadi dalam pembelajaran tematik di Kelas V SD Pesurungan Lor 2 Kota Tegal. Guru kesulitan dalam mengajar dan mengevaluasi hasil pembelajaran. Peserta didik mengalami kesulitan belajar sehingga menghambat proses pembelajaran dan tidak mampu menguasai kompetensi yang dituntut dalam Kurikulum 2013. Penelitian ini bertujuan untuk : (1) untuk melakukan inovasi dalam mengoptimalkan pemahaman materi pembelajaran tematik Kurikulum 2013; (2) untuk mengetahui pemahaman peserta didik Kelas $\mathrm{V}$ tentang materi pembelajaran tematik Kurikulum 2013; (3) untuk meningkatkan hasil pembelajaran tematik peserta didik Kelas V. Penelitian ini menggunakan metode Fishbone Analysis dan GAP Analysis. Penggunaan Kartu Refleksi dilakukan oleh peserta didik setiap selesai pembelajaran tematik dengan menuliskan apa saja yang telah dipelajari dan menyampaikan isi Kartu Refleksi agar peserta didik dapat mengingat materi sebelumnya. Jurnal Refleksi diisi oleh guru dengan memperhatikan hasil Kartu Refleksi. Penggunaan Kartu dan Jurnal Refleksi berpengaruh pada peningkatan pemahaman dan hasil belajar peserta didik.
\end{abstract}

Kata kunci: kartu refleksi, jurnal refleksi, pembelajaran tematik

Social, Humanities, and Education Studies (SHEs): Conference Series https://jurnal.uns.ac.id/shes

p-ISSN 2620-9284 e-ISSN 2620-9292 


\section{PENDAHULUAN}

Undang-Undang Republik Indonesia Nomor 20 Tahun 2003 tentang Sistem Pendidikan Nasional menyatakan bahwa pendidikan merupakan usaha sadar dan terencana untuk mewujudkan suasana belajar dan proses pembelajaran agar peserta didik dapat mengembangkan potensi yang dimilikinya. Tujuan pembelajaran merupakan orientasi dari keberhasilan suatu pembelajaran yang telah dilakukan. Pembelajaran dikatakan berhasil manakala tujuan dari pembelajaran yang ditetapkan tersebut dapat tercapai dengan baik. Namun, dalam pembelajaran seringkali terdapat permasalahan yang terjadi yang menghambat ketercapaiannya hal tersebut. Kurikulum yang baru yaitu Kurikulum 2013 memiliki perbedaan yang cukup besar dibandingkan dengan Kurikulum 2006 yang sebelumnya diterapkan di dunia pendidikan. Perbedaan ini membuat guru kesulitan dalam mengajar dan mengevaluasi dan peserta didik mengalami kesulitan belajar sehingga menghambat proses pembelajaran dan menyebabkan peserta didik tidak mampu menguasai kompetensi yang dituntutkan dalam kurikulum baik secara akademis maupun secara sikap yang berkarakter.

Realita di SD Pesurungan Lor 2 Kota Tegal, kelas-kelas yang sudah menggunakan Kurikulum 2013 ternyata masih sulit menerapkan pembelajaran tematik yang membuat banyak peserta didik tidak paham materi yang diajarkan sehingga banyak peserta didik yang nilai evaluasinya rendah. Pergantian kurikulum dari Kurikulum 2006 menjadi Kurikulum 2013 menjadi tantangan bagi segala aspek pendidikan. Kurikulum 2013 yang menekankan pembelajaran tematik dan pendidikan karakter membuat guru harus berusaha lebih keras dalam menerapkan student center dan mengurangi pembelajaran konvensional. Banyak guru yang belum optimal dalam menerapkan pembelajaran tematik Kurikulum 2013. Guru masih membeda-bedakan materi sesuai mata pelajaran seperti Kurikulum 2006. Padahal di Kurikulum 2013 sudah tidak menerapkan mata pelajaran (mapel), tetapi muatan pelajaran (mupel) Ini menyebabkan penyampaian materi yang diberikan oleh guru akhirnya tidak dipahami oleh peserta didik sehingga menyebabkan hasil belajar yang didapat peserta didik rendah. Belum adanya alat untuk merefleksi hasil pembelajaran yang sudah dipahami oleh peserta didik sehingga guru terkadang menganggap peserta didik sudah memahami semua materi.

Berdasarkan uraian latar belakang di atas dapat dirumuskan masalah sebagai berikut:

1. Bagaimana meningkatkan pemahaman mengenai materi pembelajaran tematik peserta didik kelas V SD Pesurungan Lor 2 Kota Tegal ?

2. Bagaimana meningkatkan hasil belajar materi tematik peserta didik kelas $\mathrm{V}$ SDPesurungan Lor 2 Kota Tegal?

3. Apakah solusi inovatif yang dapat diterapkan untuk membantu guru dala proses pembelajaran materi tematik di Kelas V SD Pesurungan Lor 2 Kota Tegal?

Dari uraian latar belakang dan rumusan masalah di atas penelitian ini secara umum memiliki tujuan untuk mengatasi masalah yang terjadi pada pembelajaran supaya pembelajaran yang berlangsung mendapatkan hasil yang lebih baik sehingga prestasi belajar siswa meningkat. Sedangkan secara khusus tujuan dari penelitian ini adalah sebagai berikut

1) Untuk melakukan inovasi dalam mengoptimalkan pemahaman materi pembelajaran tematik Kurikulum 2013;

2) Untuk mengetahui pemahaman peserta didik Kelas V SD Pesurungan Lor 2 Kota Tegal tentang materi pembelajaran tematik Kurikulum 2013;

3) Untuk meningkatkan hasil pembelajaran tematik peserta didik Kelas V SD Pesurungan Lor 2 Kota Tegal.

\section{METODE}


Metode yang digunakan dalam penelitian ini adalah penelitian kualitatif dengan melakukan identifikasi akar permasalahan telebih dahulu untuk menentukan solusi dengan menggunakan metode fishbone analysis. Setelah ditemukan akar masalah, selanjutnya penulis melakukan GAP Analysis untuk menemukan hal yang dapat dioptimalkan. Dari GAP Analysis, didapatkan solusi inovatif yang mampu diterapkan di Kelas V. Solusi inovatif yang akan dikerjakan adalah penggunaan KJR (Kartu dan Jurnal Refleksi) untuk optimalisasi pembelajaran tematik di kelas V SD Pesurungan Lor 2 Kota Tegal.

Penelitian dilakukan dengan empat tahap yaitu tahap koordinasi, tahap perencanaan dan persiapan, tahap penelitian, tahap analisis data dan evaluasi , dan tahap refleksi.

Jenis data dalam penelitian ini meliputi kata-kata dan tindakan, sumber data tertulis, foto, dan data statistik. Teknik pengumpulan data yang digunakan dalam penelitian ini menggunakan metode tes, observasi, wawancara,dan dokumentasi. "Tes adalah serentetan pertanyaan atau latihan serta alat lain yang digunakan untuk mengukur ketrampilan, pengetahuan intelegensi, kemampuan atau bakat yang dimiliki oleh individu atau kelompok" (Arikunto, 2009).

Data yang terkumpul kemudian diuji keabsahanya melalui uji keabsahan data dengan metode triangulasi. Data yang telah terkumpul kemudian masuk dalam tahapan analisis data, proses analisis data kualitatif menurut Siedel (1982) dalam Moleong (2012: 248) antara lain: (1) mencatat dapa apapun yang didapat; (2) mengumpulkan, memilahmilah, mengklasifikasikan dan membuat ikhtisar; (3) berfikir guna mencari pola antar ketegori, serta hubungan antar kategori serta membuat temuan-temuan umum.

\section{HASIL DAN PEMBAHASAN}

Refleksi pembelajaran adalah suatu komponen kegiatan yang dilaksanakan setelah proses pembelajaran dengan tujuan untuk menilai dan mengamatii apa yang telah terjadi selama pembelajaran berlangsung. Berdasarkan Permendiknas Nomor 16 Tahun 2007 tentang Standar Kualifikasi Akademik dan Kompetensi Guru disebutkan bahwa guru senantiasa harus melakukan refleksi untuk peningkatan kualitas pembelajaran (kompetensi pedagogik).

1. KR (Kartu Refleksi)

KR (Kartu Refleksi) adalah kartu yang berisi materi pembelajaran yang telah dipelajari dalam satu hari. Nantinya KR (Kartu Refleksi) ini diisi oleh peserta didik setelah pembelajaran selesai dan sebelum peserta didik pulang sekolah. Bagi peserta didik yang memahami materi pembelajaran hari itu, akan mudah mengisikan KR (Kartu Refleksi). Namun, bagi peserta didik yang belum memahami, akan kesulitan saat diminta mengisi KR (Kartu Refleksi). Setelah itu, guru meminta peserta didik untuk membacakan KR (Kartu Refleksi) masing-masing sebelum dikumpulkan. KR (Kartu Refleksi) yang terbaik akan dibacakan kembali saat pembelajaran keesokan harinya sebagai salah satu apersepsi.

Peneliti terinspirasi dari pengalaman saat peneliti masih duduk di bangku Sekolah Dasar. Guru menugaskan peserta didik untuk merangkum materi pembelajaran dalam sebuah kartu. Kartu ini dikumpulkan dan dibagikan ke peserta didik setiap pulang sekolah untuk dibaca di rumah. Sebelum masuk kelas keesokan harinya, peserta didik diminta untuk menceritakan apa yang peserta didik baca dari kartu tersebut. Jika ada peserta didik yang belum bisa menceritakan, guru akan memberikan waktu lagi dan menugaskan untuk merangkum materi yang lain.

2. JR (Jurnal Refleksi)

Dikutip dari laman kompasiana.com, jurnal refleksi adalah catatan sesudah guru mengajar di kelas tentang kelebihan dan kekurangan guru mengajar di kelas yang guru kunjungi, baik tentang metode mengajar yang digunakan, perangkat yang digunakan, situasi kelas, cara mengatasi peserta didik dan lain-lain. Namun di 
aktualisasi ini peneliti memfokuskan jurnal refleksi untuk peserta didik. Pengisian JR (Jurnal Refleksi) ini berdasarkan apa yang sudah ditulis oleh peserta didik dalam KR (Kartu Refleksi).

Selama proses pembelajaran berlangsung, peserta didik tidak hanya bekerja secara individu, tetapi juga berkelompok sesuai dengan yang diharapkan pada pembelajaran tematik Kurikulum 2013. Penentuan anggota kelompok dibuat acak setiap minggunya, sehingga diharapkan peserta didik tidak bosan dan dapat berinteraksi dengan peserta didik lainnya.

Pengisian KR (Kartu Refleksi) dilakukan setiap selesai pembelajaran tematik dalam satu hari. Peserta didik diberi waktu 15- 10 menit untuk menuliskan di KR (Kartu Refleksi) apa yang mereka pelajari hari ini. Kemudian KR (Kartu Refleksi) dikumpulkan dan diperiksa oleh guru. Guru menuliskan hasil dari Kartu Refleksi masing-masing peserta didik di Jurnal Refleksi. Keesokan harinya, setelah pembiasaan, peserta didik membacakan KR (Kartu Refleksi) yang sudah peserta didik tulis sebelumnya di depan peserta didik lainnya. Ini dilakukan agar peserta didik daapat mengingat kembali materi yang pernah dipelajari sebelumnya. Setiap peserta didik yang menulis KR (Kartu Refleksi) akan mendapatkan stiker yang akan ditempelkan pada Book of Reward milik masing-masing peserta didik. Selanjutnya berdasarkan hasil rubrik penilaian siswa dan hasil Book of Reward, dipilih para peserta didik terbaik. Pemberian reward diharapkan dapat memotivasi siswa untuk terus semangat belajar.

Setelah dilaksanakan refleksi pembelajaran menggunakan Kartu dan Jurnal Refleksi, pada pembelajaran Tema 2 dan Tema 2 hasil belajar peserta didik mengalami peningkatan. Hal ini dipengaruhi beberapa faktor antara lain guru dan peserta didik terlibat komunikasi dua arah ketika pembelajaran, peserta didik lebih tertarik dan aktif saat pembelajaran berlangsung.

Data hasil belajar peserta didik pada Tema 1, pre-test Tema 2 dan Tema 2 adalah sebagai berikut :

Tabel 1. Rekapitulasi Hasil Belajar Peserta didik Kelas V

\begin{tabular}{lccc}
\hline \multicolumn{1}{c}{ Aspek } & Tema 1 & $\begin{array}{c}\text { Pre-test } \\
\text { Tema 2 }\end{array}$ & Tema 2 \\
\hline Nilai Rata-rata & 57 & 65 & 70 \\
Nilai tertinggi & 73 & 78 & 85 \\
Nilai terendah & 20 & 35 & 40 \\
$\begin{array}{l}\text { Peserta didik yang Tuntas } \\
\begin{array}{l}\text { Peserta didik yang belum } \\
\text { Tuntas }\end{array}\end{array}$ & 10 & 16 & 21 \\
$\begin{array}{l}\text { Prosentase peserta didik } \\
\text { Tuntas }\end{array}$ & $37,04 \%$ & $59,26 \%$ & $77,78 \%$ \\
$\begin{array}{l}\text { Prosentase peserta didik } \\
\text { belum Tuntas }\end{array}$ & $62,96 \%$ & $40,74 \%$ & $22,22 \%$ \\
\hline
\end{tabular}

Dari tabel di atas dapat dilihat bahwa pada Tema 1 masih banyak peserta didik yang belum memenuhi batas KKM dan prosentasi ketuntasan secara klasikal belum mencapai $75 \%$. Dari data yang diperoleh pada Tema 1, peserta didik yang telah mencapai KKM sebanyak 37,04\% atau hanya 10 peserta didik dan 62,96\% atau 17 peserta didik belum mencapai KKM. Nilai rata-rata kelas dari 27 peserta didik adalah 57, nilai tertinggi yaitu 73 dan nilai terendah 20. Berdasarkan hal ini peneliti mencoba untuk melakukan tindakan refleksi dengan menggunakan Kartu Refleksi pada peserta didik 
kelas $\mathrm{V}$ untuk mengetahui sejauh mana pemahaman peserta didik mengenai materi pembelajaran tematik.

Pada kegiatan pembelajaran setelah dilakukan penggunaan Kartu Refleksi bisa dilihat saat pre-test Tema 2 terjadi peningkatan nilai peserta didik kelas V. Nilai rata-rata peserta didik menunjukkan bahwa hasil pembelajaran tematik cukup memuaskan karena sebanyak 59,26\% atau 16 peserta didik sudah mencapai nilai KKM dan sebanyak $40,74 \%$ atau 11 peserta didik belum mencapai KKM. Nilai rata-rata kelas dari 27 peserta didik adalah 65, nilai tertinggi yaitu 78 dan nilai terendah 35.

Pada pelaksanan pembelajaran Tema 2 peserta didik yang telah mencapai KKM sebanyak $77,78 \%$ atau 21 peserta didik dan 22,22\% atau 6 pesertadidik belum mencapai KKM. Nilai tertinggi pesera didik adalah 85 dan nilai terendah adalah 40 . Walaupun pada Tema 2 masih ada peserta didik yang belum mencapai KKM tetapi dari data yang didapatkan sudah menunjukkan peningkatan dan sudah menunjukkan hasil yang termasuk sangat memuaskan, karena sudah mencapai indikator keberhasilan klasikal yang telah ditetapkan yaitu ketuntasan belajar peserta didik minimal $75 \%$.

Di bawah ini disajikan sebuah diagram peningkatan hasil pembelajaran materi tematik dari Tema 1 sampai Tema 2:

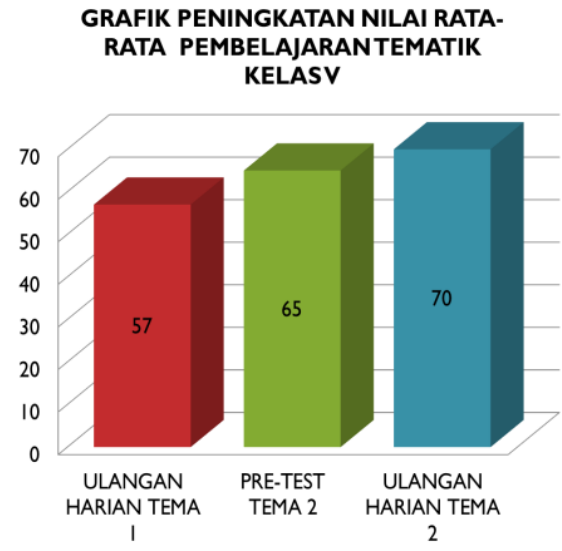

Gambar 1. Grafik peningkatan nilai rata-rata pembelajaran tematik kelas V

Terwujudnya pembelajaran yang efektif dan bermakna bagi peserta didik, suasana belajar yang menyenangkan dan meningkatkan hasil belajar peserta didik karena tingkat pemahaman peserta didik terhadap materi pelajaran dapat merata. Peserta didik lebih aktif, semangat, dan fokus dalam mengikuti kegiatan belajar mengajar sehingga memberikan dampak peningkatan hasil belajar peserta didik. Hal tersebut sejalan dengan penelitian yang dilakukan oleh Amnah Nur Alfiah, Ngurah Made Darma Putra dan Bambang Subali pada tahun 2018 yang berjudul Media Scrapbook sebagai Jurnal Refleksi untuk Meningkatkan Kemampuan Kognitif dan Regulasi Diri.

Dari data tersebut dapat diketahui bahwa penggunaan Kartu dan Jurnal Refleksi terbukti menjadi solusi inovatif untuk mengoptimalisasi pembelaajaran teatik di sekolah. Penggunaan Kartu dan Jurnal Refleksi ini dapat membuat peserta didik lebih memahami materi pembelajaran tematik. Selain itu, meningkatkan hasil belajar peserta didik Kelas V SD Pesurungan Lor 2 Kota Tegal.

\section{SIMPULAN}

Berdasarkan hasil penelitian dan pembahasan, secara umum penggunaan KJR (Kartu dan Jurnal Refleksi) untuk optimalisasi pembelajaran tematik di kelas V SD Pesurungan Lor 2 ini mampu mengatasi masalah kurang optimalnya pemahaman materi 
pembelajaran tematik sehingga berpengaruh pada peningkatan prestasi dan hasil belajar peserta didik. Dengan adanya penggunaan KJR (Kartu dan Jurnal Refleksi) ini diharapkan dapat menjadi solusi inovatif terhadap keluhan peserta didik dalam memahami materi pembelajaran tematik, sehingga tujuan pembelajaran yang ditetapkan dapat tercapai dengan baik, dan siswa dalam kelas secara merata mampu memahami materi pelajaran yang disampaikan. Apabila kondisi tersebut dapat tercapai maka secara langsung dapat berkontribusi terhadap pembangunan negara khususnya bidang pendidikan di Sekolah Dasar.

\section{DAFTAR PUSTAKA}

Alfiah, Amnah Nur, dkk. 2018. Media Scrapbook sebagai Jurnal Regleksi untuk Meningkatkan Kemampuan Kognitif dan Regulasi Diri. Online. https://journal.unesa.ac.id/index.php/jp/article/view/2027 [Diakses pada 04/08/2019/08.30].

Hartati, Dede Sri.2016.Jurnal Refleksi Guru (Sebuah Media Peningkatan Kualitaas Pembelajaran di Kelas). Online https://www.kompasiana.com/dedesri/583ce8ac757a619b26778624/refleksipembelajaran?page=all [Diakses pada 05/08/2019/18.30].

Moleong, Lexy. 2012. Metodologi Penelitian Kualitatif. Bandung: PT Remaja Rosdakarya Offset.

Prasetyo, E. (2015). Pembelajaran Reflektif Berbasis Jurnal Belajar Untuk Meningkatkan Penguasaan Konsep dan Strategi Metakognitif Siswa. Universitas Negeri Semarang.

Susanto, Ahmad. 2013. Teori Belajar dan Pembelajaran di Sekolah Dasar. Jakarta: Kencana Prenada Media Group.

Undang-undang No.20 Tahun 2003 tentang Sistem Pendidikan Nasional. Online. www.dikti.go.id/files/atur/UU20-2003Sisdiknas.pdf . [Diakses pada 02/08/2019/01.00]. 